\title{
Variations in the fecundity and body size of digenean (Opecoelidae) species parasitizing fishes from Northern Chile
}

\author{
Variaciones en la fecundidad y tamaño corporal de especies digeneas (Opecoelidae) \\ que parasitan peces del norte de Chile
}

\section{Teresa González ${ }^{1}$, Vania Henríquez ${ }^{1}$ and Zambra López ${ }^{2}$}

\begin{abstract}
${ }^{1}$ Instituto de Investigaciones Oceanológicas, Facultad de Recursos del Mar, Universidad de Antofagasta, Casilla 117, Antofagasta, Chile.mtgonzalez@uantof.cl

${ }^{2}$ Programa Magíster en Ecología de Sistemas Acuáticos, Universidad de Antofagasta, Casilla 117, Antofagasta, Chile

Resumen.- La historia de vida y estrategias de reproducción de los parásitos muestran una variabilidad significativa asociada con la identidad de hospedador y con factores ambientales. Este estudio evaluó la influencia de las especies hospedadoras sobre algunos rasgos de historia de vida de digeneos, como el tamaño del cuerpo del parásito (PBL) y la fecundidad, de 3 especies: Helicometra fasciata, Helicometrina nimia y Neoleburia georgenascimentoi. Además, se usaron marcadores moleculares (región V4 del gen $18 \mathrm{~S}$ y CO-I)para confirmar la identidad específica de las especies parásitas en los diferentes hospedadores. Desde enero 2010 hasta junio 2012, 305 peces pertenecientes a Paralabrax humeralis, Acanthistius pictus, Labrisomus philippii, Prolatilus jugularis y Pinguipes chilensis fueron capturados, por medio de buceo, desde la costa norte de Chile $\left(24^{\circ} \mathrm{S}\right)$. En el laboratorio, los peces se midieron y se recolectaron todos sus parásitos. A cada parásito objetivo se le midió la longitud total y el ancho del cuerpo y todos sus huevos extraídos del útero se contabilizaron. Se utilizaron modelos lineales generalizados (GLM) para identificar los factores que afectan la fecundidad de los digeneos. La fecundidad de H. nimia fue mayor en A. pictus y menor en L. philippii; la fecundidad de $\mathrm{H}$. fasciata fue mayor en $\mathrm{P}$. humeralis y menor en L. philippii y la fecundidad de N. georgenascimentoi fue mayor en P. chilensis. GLM mostraron que la fecundidad es afectada por el PBL y por la especie hospedadora. Las variaciones en PBL y fecundidad están aparentemente asociados con el tamaño de las especies hospedadoras: los parásitos más grandes (y con mayor fecundidad) se registraron en las especies de peces con mayores tamaños corporales (P. humeralis; A. pictus y P. chilensis). No obstante, los análisis moleculares mostraron que $\mathrm{H}$. nimia presente en L. philippii difiere a las encontradas en A. pictus y $\mathrm{P}$. humeralis, mientras que N. georgenascimentoi presente en P. jugularis es distinta a la encontrada en P. chilensis; por lo tanto, la identidad específica de los digeneos podría explicar la diferencia en su fecundidad entre especies de hospedadores.
\end{abstract}

Palabras clave: Helicometra, Helicometrina, Neoleburia, Serranidae, Labrisomidae, Pinguipidae, ADNm

\begin{abstract}
Parasite life history and reproductive strategies show considerable variability associated with host identity and/or environmental factors. In this study, we measured parasite body length (PBL) and fecundity of 3 digenean species: Helicometra fasciata, Helicometrina nimia and Neoleburia georgenascimentoi, in their different host species, to evaluate the host influence on these biological traits. Additionally, parasite identifications were confirmed using molecular markers (V4 region of $18 \mathrm{~S}$ and CO-I genes). From January 2010 to June 2012, 305 fish belonging to Paralabrax humeralis, Acanthistius pictus; Labrisomus philippii; Prolatilus jugularis and Pinguipes chilensis were captured, by diving, off the northern Chilean coast $\left(24^{\circ} \mathrm{S}\right)$. In the laboratory, fish were measured and all their parasites collected. The total length and body width of each individual parasite were measured and all eggs were extracted from the parasites' uterus and counted. Generalized lineal models were used to identify factors affecting fecundity of digeneans. Fecundity of $\mathrm{H}$. nimia was highest in A. pictus and lowest in individuals from L. philippii; fecundity of $\mathrm{H}$. fasciata was highest in P. humeralis and lowest in L. philippii and fecundity of N. georgenascimentoi was highest in P. chilensis. GLM showed that variations in fecundity of digeneans are explained by host fish species and by PBL. Variations in PBL and fecundity are apparently associated with host species sizes: longer parasites (with more eggs per parasite) were recorded in larger fish species (P. humeralis, A. pictus and P. chilensis). However, molecular analyses showed that H. nimia from L. philippii should be considered a distinct species from specimens found in A. pictus and P. humeralis, while N. georgenascimentoi from P. jugularis should be considered a distinct species from specimens found in P. chilensis, which might explain the observed fecundity differences in those host species.
\end{abstract}

Key words: Helicometra, Helicometrina, Neoleburia, Serranidae, Labrisomidae, Pinguipidae, mDNA 


\section{INTRODUCTION}

Parasite life history and reproductive strategies show considerable variability associated with host identity (Krasnov et al. 2004, Riquelme et al. 2006, González et al. 2012) or environmental factors (Pietrock \& Marcogliese 2003, Poulin 2007). There is evidence that the host immunity can affect parasite fitness (Tschirren et al. 2007) and some studies have highlighted its role in controlling helminth populations (Meeusen \& Balic 2000). Given that the host immune system represents a strong selective force on parasite success (Morand \& Sorci 1998), parasites lacking sufficient adaptations may exhibit depressed fecundity (Trouve et al. 1998).

If generalist parasites (= those infecting several host species) need to develop counter-adaptations against the immune systems of many potential hosts, specialist parasites (= those infecting only one or two host species) can allocate more resources to reproduction or other functions, resulting in a trade-off between the number of host species that can be successfully exploited and parasite success in those hosts (Poulin \& Mouillot 2004). Consequently, parasite species with low host specificity may have evolved in less advantageous conditions than those that are more host-specific (Sasal et al. 1999), which could then affect the life-history strategies of each one; and in turn, determine the host-specific levels of parasite abundance (Krasnov et al. 2006). Thus, host specificity takes into account epidemiological indices, such as the percentage of infected host species or the intensity of infection, which may reveal stronger host-parasite interactions (Sasal et al. 1999), and host specificity is recognized as a key factor determining the spread of parasitic diseases (Gemmill et al. 2000).

Parasite identifications are based almost exclusively on morphological characters. However, over the last decade the use of molecular markers has been applied widely as a powerful tool in taxonomy, systematics and phylogeny, allowing to assess whether or not morphological variations correspond to different parasite species or it corresponds only to phenotypic expression of the same species due to environmental variations (Hebert et al. 2004, Radulovici et al. 2010).

Off the northern Chilean coast, fish species such as Brick seabass Acanthistius pictus, Peruvian rock seabass, Paralabrax humeralis (Serranidae) and Chalapo clinid Labrisomus philippii (Labrisomidae) are parasitized by 2 digenean species, Helicometrina nimia and Helicometra fasciata. The serranid species reach similar body length and overlap in habitats associated with seaweeds, e.g., Lessonia nigrescens and Macrocystis spp. (Cisternas \& Sielfeld 2008); whereas L. philippii reach lower body length and inhabits demersal habitats (Medina et al. 2004). Similarly, both Pinguipes chilensis and Prolatilus jugularis (Pinguipidae) are hosts to the digenean Neoleburia georgenascimentoi. The latter 2 host species differ in body length and habitat preference (González \& Oliva 2008).

In this study, parasite body length and fecundity were measured for these 3 digenean species (H. fasciata, $H$ nimia and $N$. georgenascimentoi) in the different host species, to evaluate the influence of the host species on these biological traits and, additionally, parasite identifications were confirmed using molecular markers (V4 region of $18 \mathrm{~S}$ and CO-I genes). Significant differences in the biological traits among host species can be expected if extrinsic factors are identified as key determinants of reproductive success for these parasites.

\section{Materials And Methods}

\section{SAMPling AND DATA COLleCtion}

From January 2010 to June 2012, 305 fish belonging to Paralabrax humeralis, Acanthistius pictus; Labrisomus philippii; Prolatilus jugularis and Pinguipes chilensis were captured, by diving, from northern Chilean coast (Isla Santa María, ISM, $24^{\circ} \mathrm{S}$ ). In the laboratory, the fish were measured and examined, and all parasites were collected using traditional parasitology techniques following González \& Poulin (2005). Parasites were sorted, counted, and preserved in $70 \%$ alcohol for subsequent analyses prior to being identified based on morphological features, following Bray (2002) and Jones et al. (2005), as Helicometra fasciata, Helicometrina nimia and Neoleburia georgenascimentoi. The number of fish examined by host species, the prevalence, means abundance and means intensity of the digeneans (sensu Bush et al. 1997) in the different host species are summarised in Table 1.

Given that the number of eggs in the uterus can be a snapshot of one continuous process of egg production and release (Herreras et al. 2007), fish samples were obtained at different times during year to avoid potential monthly reproductive peak of the digeneans. The total length was measured from relaxed specimens of the selected digenean parasites using a compound 
Table 1. Mean abundance (A), mean intensity and prevalence (P\%) of the digeneans Helicometra fasciata, Helicometrina nimia and Neoleburia georgenascimentoi in the different host species from Northern Chilean coast / Abundancia media (A), intensidad media (I) y prevalencia (P\%) de los digeneos Helicometra fasciata, Helicometrina nimia and Neoleburia georgenascimentoi en los diferentes especies hospedadoras del norte de Chile

\begin{tabular}{|c|c|c|c|c|c|c|c|c|c|}
\hline \multirow[t]{3}{*}{ Host fish species } & \multicolumn{9}{|c|}{ Digenean species } \\
\hline & \multicolumn{3}{|c|}{ Helicometra fasciata } & \multicolumn{3}{|c|}{ Helicometrina nimia } & \multicolumn{3}{|c|}{ Neoleburia georgenascimentoi } \\
\hline & $\mathrm{A}$ & $\mathrm{I}$ & $\mathrm{P} \%$ & A & I & $\mathrm{P} \%$ & A & $\mathrm{I}$ & $\mathrm{P} \%$ \\
\hline A. pictus $(\mathrm{n}=41)$ & 0.76 & 6.1 & 7.3 & 0.07 & 1.5 & 7.3 & & & \\
\hline P. humeralis $(\mathrm{n}=49)$ & 2.33 & 7.0 & 40.8 & 0.35 & 3.6 & 10.2 & & & \\
\hline L. philippii $(\mathrm{n}=70)$ & 0.65 & 3.0 & 18.2 & 3.47 & 6.1 & 57.5 & & & \\
\hline P. jugularis $(\mathrm{n}=72)$ & & & & & & & 1.17 & 3.00 & 29.4 \\
\hline P. chilensis $(\mathrm{n}=64)$ & & & & & & & 0.76 & 4.08 & 18.8 \\
\hline
\end{tabular}

microscope. Eggs were extracted from the uterus of each of the target parasites and counted. Fecundity was defined as total number of eggs per parasite individual.

\section{Statistical anAlyses}

In total, 550 parasites were measured (212 of $H$. fasciata, 228 of $H$. nimia and 110 of $N$. georgenascimentoi). The intensity of infection of these digenean species varied between 1 and 18 parasites per fish. Therefore, the median value was used in statistical analyses when there was more than one individual parasite by fish (Table 2).

Because the data set for $H$. nimia and $H$. fasciata did not meet the requirement of homogeneity of variances, Kruskal-Wallis tests were used to evaluate PBL differences among fish species. For $N$. georgenascimentoi, the difference in PBL (log- transformed data) between host species was evaluated with a Student t-test (Zar 1999)

Generalized lineal models (GLM) were used to evaluate fecundity (number of eggs per parasite individual) among fish species, including in the models the variables PBL, fish size and intensity of infection. Given that fish size varied significantly among host fish species, a stepwise model was used to evaluate the effect of. The models were performed using distribution normal for response variable (log-transformed), and as normal link function (Quinn \& Keough 2002). All analyses were performed in software STATISTICA 7.0.

\footnotetext{
${ }^{1}$ Macrogen Inc., Seoul, Korea <http://www.macrogen.com>
}

\section{Molecular analyses}

Recent literature has shown the presence of cryptic parasite species in different hosts. Hence, molecular analyses were performed using region $\mathrm{V} 4$ region of the $18 \mathrm{~S}$ ribosomal RNA (V4) and these were supplemented with partial cytochrome oxidase subunit I (COI) sequence to confirm the identifications of $N$. georgenascimentoi, Helicometra fasciata and Helicometrina nimia from the different host species.

For molecular analyses, the parasites were isolated and transfered to a 1.5-ml microcentrifuge tube (one in each tube). DNA extraction was performed according to Leung et al. (2009). The V4 and partial COI gene were amplified by polymerase chain reaction (PCR) using the primers and methodology (including the amplification protocols) described by Hall et al. (1999). The PCR products were visualised on a $1.5 \%$ agarose gel and sequenced using an automated capillary electrophoresis sequencer (ABI 3730XL, Macrogen Inc. $)^{1}$. The similitude tree reconstruction was performed using the software Mega 5 (Tamura et al. 2011), the algorithm Neighbor-Joining (NJ) (Nei \& Kumar 2000), and the evolution model Kimura 2-parameter (K2P) (Kimura 1980). Nodal support was assessed using 1000 bootstrap resamplings (Efron 1982). Lobatostoma manteri (L16911.1) and Aspidogaster conchicola (DQ482608.1) were used as outgroups for the V4. Haliotrema aurigae (EU009803.1) and Macrogyrodactylus clarii (GU252718.1) were used as outgroup for COI. These sequences were obtained from Genbank. 


\section{Results}

\section{Population PaRameters of THE Digeneans}

The highest $H$. nimia prevalence was recorded in $L$. philippii, whereas the highest of $H$. fasciata prevalence was in $P$. humeralis. The lowest prevalences of these digeneans were in A. pictus. For N. georgenascimentoi, the prevalence was higher in Prolatilus jugularis than in Pinguipes chilensis (Table 1).

\section{Parasite body length and fecundity}

The number of individuals measured, range of variations in the parasite body length (PBL), body width and number of eggs per parasite for each digenean species within their host fish species is summarised in Table 2 .

PBL of H. nimia $\left(\mathrm{H}_{2,165}=74.19, P<0.001\right), H$. fasciata $\left(\mathrm{H}_{2,96}=9.4, P=0.009\right)$ and $N$. georgenascimentoi $(\mathrm{t}=2.18$, $\mathrm{df}=69, P=0.03)$ varied significantly among host fish species. Individuals of $H$. nimia were longest in A. pictus and smallest in L. philippii, whereas individuals of $H$.

Table 2. Mean parasite body length (PBL, $\mathrm{mm}$ ), mean number of eggs by parasite and mean intensity of the digenean species in the different host species. In parenthesis, is given standard deviation. $\mathbf{N}=$ Number of examined individual parasites / Longitud promedio del cuerpo del parásito ( $\mathrm{PBL}, \mathrm{mm}$ ), número promedio de huevos por parásito e intensidad media de las especies de digeneos en los diferentes hospedadores. En paréntesis se entrega la desviación estándar. $\mathrm{N}$ = número de parásitos examinados

\begin{tabular}{|c|c|c|c|}
\hline & \multicolumn{3}{|c|}{ Host fish species } \\
\hline & A. pictus & P. humeralis & L. philippii \\
\hline \multicolumn{4}{|l|}{ Helicometrina nimia } \\
\hline PBL (mm) & 5.7 (1.58) & $3.3(1.4)$ & $2.11(0.5)$ \\
\hline Parasite body width (mm) & $1.4(0.35)$ & $0.8(0.3)$ & $0.6(0.1)$ \\
\hline $\mathrm{N}^{\circ}$ eggs/parasite & $326.6(150.1)$ & $104.9(85.5)$ & $47.1(28.1)$ \\
\hline Intensity & $8.6(5.6)$ & $5.4(5.1)$ & $10.1(5.5)$ \\
\hline Fish size $(\mathrm{cm})$ & $34.3(3.0)$ & $35.9(6.9)$ & $26.1(3.1)$ \\
\hline $\mathrm{N}$ & 40 & 46 & 60 \\
\hline \multicolumn{4}{|l|}{ Helicometra fasciata } \\
\hline PBL (mm) & $2.5(0.6)$ & $2.6(0.7)$ & $2.1(0.4)$ \\
\hline Parasite body width (mm) & $0.6(0.1)$ & $0.7(0.2)$ & $0.6(0.1)$ \\
\hline $\mathrm{N}^{\circ}$ eggs/parasite & $103.2(80.4)$ & $150.8(73.4)$ & $60.2(43.7)$ \\
\hline Intensity & $13.5(6.4)$ & $12.6(7.8)$ & $3.95(1.7)$ \\
\hline Fish size $(\mathrm{cm})$ & $35.8(3.7)$ & $36.2(6.9)$ & $26.9(4.0)$ \\
\hline $\mathrm{N}$ & 43 & 34 & 19 \\
\hline N. georgenascimentoi & P. jugularis & P. chilensis & \\
\hline PBL (mm) & $2.7(0.6)$ & $3.2(0.72)$ & \\
\hline Parasite body width $(\mathrm{mm})$ & $0.8(0.2)$ & $0.8(0.4)$ & \\
\hline $\mathrm{N}^{\circ}$ eggs/parasite & $152.9(120.5)$ & $300.1(217.8)$ & \\
\hline Intensity & $12.9(5.4)$ & $5.9(3.8)$ & \\
\hline Fish size $(\mathrm{cm})$ & $32.8(4.0)$ & $41.9(4.3)$ & \\
\hline $\mathrm{N}$ & 35 & 42 & \\
\hline
\end{tabular}

fasciata were longest in $P$. humeralis and smallest in $L$. philippii. Individuals of $N$. georgenascimentoi were longest in P. chilensis (Table 2).

Fecundity of $H$. nimia was highest in Acanthistius pictus and lowest in individuals from L. philippii, whereas fecundity of $H$. fasciata was highest in $P$. humeralis and lowest in L. philippii (Table 2). On the other hand, fecundity of $N$. georgenascimentoi was highest in $P$. chilensis (Table 2). GLM showed that variation in fecundity of digeneans is explained by host fish species and by PBL (Table 3). Consequently, in those host species where the parasites showed longest body length, they also recorded the highest fecundities.

\section{Molecular analyses}

For the V4, a total of 9 sequences from $N$. georgenascimentoi (5 sequences from $P$. chilensis and 4 from $P$. jugularis), 10 sequences from $H$. fasciata (2 from L. philippii, 5 from $P$. humeralis and 3 from A. pictus) and 9 sequences from $H$. nimia (4 from L. philippii, 3 from $A$. pictus and 2 from $P$. humeralis) were obtained. All sequences were $414 \mathrm{bp}$ in length.

$N$. georgenascimentoi of both host fish grouped in the same clade with a bootstrap support of $99 \%$, although the $N$. georgenascimentoi collected from $P$. jugularis were located in one subgroup with a bootstrap support of $65 \%$. Only $0.3 \%$ of genetic distance (1 bp difference) was observed between the $N$. georgenascimentoi isolates from $P$. chilensis and $P$. jugularis; there were no significant differences within each subgroup, supporting the specific identity of $N$. georgenascimentoi in both host fish species. Similarly, H. fasciata of the 3 host species grouped in the same clade with a bootstrap support of $99 \%$. The genetic distance was only $0.3 \%$ (1 bp difference) between sequences from $A$. pictus and the other 2 host species; recording identical sequences of $H$. fasciata between $P$. humeralis and L. philippii. On the other hand, $H$. nimia isolated from A. pictus and P. humeralis grouped in the same clade ( $99 \%$ bootstrap), but those sequences from $L$. philippii were located in a separated group, with $99 \%$ bootstrap support. The genetic distance was $2.57 \%$ (10 bp difference) between sequences of $H$. nimia from $L$. philippii and those from A. pictus and P. humeralis (Fig. 1).

For COI, a total of 3 sequences of $H$. fasciata, 3 of $H$. nimia and 8 of $N$. georgenascimento $i$ were obtained. All sequences were of $737 \mathrm{bp}$ in length. The genetic distance between sequences of $H$. fasciata from $P$. humeralis and L. philippii was $0.3 \%$ ( 2 bp difference), both grouped in 
Table 3. Results of GLM of the factors that influence the fecundity of digeneans. A) Helicometra fasciata; B) Helicometrina nimia; C) Neoleburia georgenascimentoi. The Chi-square tests assess the significance of the deviance explained by each factor / Resultados del GLM que muestran los factores que afectan la fecundidad de los digeneos, A) Helicometra fasciata; B) Helicometrina nimia; C) Neoleburia georgenascimentoi. El test Chi-cuadrado determina la significancia de la deviance explicada por cada factor

\begin{tabular}{lccc}
\hline \multicolumn{1}{c}{ Factor } & $\begin{array}{c}\text { Degree of } \\
\text { Freedom }\end{array}$ & Chi-Square & $P$ \\
\hline A) & 1 & 53.448 & $<\mathbf{0 . 0 0 1}$ \\
Log PBL & 1 & 2.649 & 0.104 \\
Log Intensity & 1 & 0.089 & $\mathbf{0 . 7 6 9}$ \\
Log Fish size & 2 & 14.998 & 0.001 \\
Host & 1 & 207.45 & $<\mathbf{0 . 0 0 1}$ \\
B) Log PBL & 1 & 0.269 & 0.603 \\
Log Intensity & 1 & 5.789 & $\mathbf{0 . 0 2 0}$ \\
Log Fish size & 2 & 9.66 & $\mathbf{0 . 0 0 7}$ \\
Host & 1 & 15.118 & $<\mathbf{0 . 0 1}$ \\
C) Log PBL & 1 & 0.725 & 0.39 \\
Log Intensity & 1 & 3.128 & $\mathbf{0 . 0 7}$ \\
Log fish size & 1 & 4.353 & $\mathbf{0 . 0 4}$ \\
Host & & & \\
\hline
\end{tabular}

the same clade, with $92 \%$ bootstrap support. The genetic distance between the sequences of $H$. nimia from $A$. pictus and L. philippii was $21.8 \%$ (161 bp difference), being located in two separated clades with $86 \%$ and $94 \%$ bootstrap support, respectively. The genetic distance between the sequences of $N$. georgenascimentoi from $P$. chilensis and P. jugularis was $16.7 \%$ (123 bp difference), being located in separated clades with $83 \%$ bootstrap support (Fig. 2). Consequently, analyses using both genes support that $H$. fasciata is present in all three fish species studied. However, in the case of $H$. nimia, the genetic differences among sequences from the fish species indicate that there is a different genetic group in $L$. philippii (Figs.1 and 2). On the other hand, the analyses for $N$. georgenascimentoi, using COI, show that each host species ( $P$. chilensis and $P$. jugularis) harbour a different genetic group (Fig. 2).

\section{Discussion}

Some studies have demonstrated that parasite biological traits, such as body length and fecundity, vary among host species (Poulin 1996, 1999, Krasnov et al. 2004,

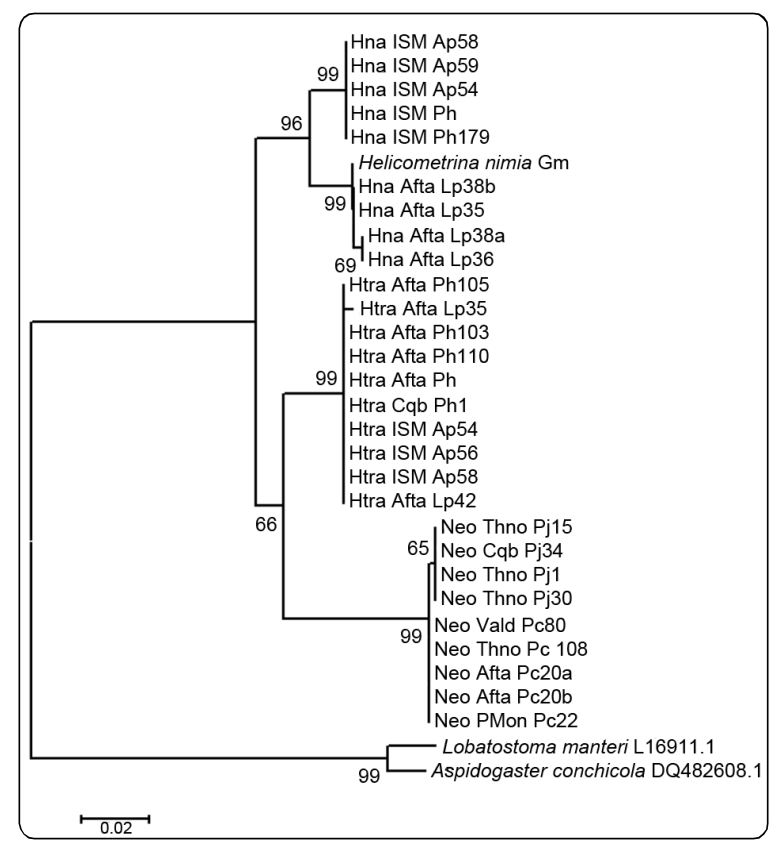

Figure 1. Phylogenetic tree of 3 digenean species present in littoral fish species from Chilean coast, based on V4 region gen $18 \mathrm{~S}$ using Neighbor Joining algorithm. Helicometra fasciata (Htra), Helicometrina nimia (Hna) and Neolebouria georgenascimentoi (Neo). Fish: Acanthistius pictus (Ap), Gobiesox marmoratus (Gm), Labrisomus philippii (Lp), Paralabrax humeralis (Ph), Pinguipes chilensis (Pc) and Prolatilus jugularis (Pj). Localities: Isla Santa M aría (ISM, $24^{\circ} \mathrm{S}$ ), Antofagasta (Afta, $24^{\circ} \mathrm{S}$ ), Coquimbo (Cqb, 30 ${ }^{\circ} \mathrm{S}$ ), Concepción (Conc, $36^{\circ} \mathrm{S}$ ), Talcahuano (Thno, $36^{\circ} \mathrm{S}$ ), Valdivia (Vald, $40^{\circ} \mathrm{S}$ ) and Puerto Montt (PMon, $40^{\circ} \mathrm{S}$ ) / Árbol filogenético de 3 especies digeneas presente en peces litorales de la costa chilena, basado en la región $\mathrm{V} 4$ del gen $18 \mathrm{~S}$ usando el algoritmo Neighbor Joining. Helicometra fasciata (Htra), Helicometrina nimia (Hna) y Neolebouria georgenascimentoi (Neo). Peces: Acanthistius pictus (Ap), Gobiesox marmoratus (Gm), Labrisomus philippii (Lp), Paralabrax humeralis (Ph), Pinguipes chilensis (Pc) y Prolatilus jugularis (Pj). Localidades: Isla Santa María (ISM, $24^{\circ} \mathrm{S}$ ), Antofagasta (Afta, $24^{\circ} \mathrm{S}$ ), Coquimbo ( $\mathrm{Cqb}, 30^{\circ} \mathrm{S}$ ), Concepción (Conc, $\left.36^{\circ} \mathrm{S}\right)$, Talcahuano (Thno, $36^{\circ} \mathrm{S}$ ), Valdivia (Vald, $40^{\circ} \mathrm{S}$ ) y Puerto Montt (PMon, $40^{\circ} \mathrm{S}$ )

Gonzalez et al. 2012). However, in one study based on an acanthocephalan/bird relationship, it was found that the fecundity of 2 digenean species of the genus Diplostomum, which shared 2 definitive hosts (birds), did not differ between the host species (Karvonen et al. 2006). In our study, the digeneans Helicometra fasciata, Helicometrina nimia and Neoleburia georgenascimentoi, recorded high fecundity and large body size, in the largest hosts: Paralabrax humeralis, Acanthistius pictus and $P$. chilensis, respectively. Whereas $P$. jugularis reach small body sizes, respect to the other fish, and had small parasites with low fecundity. It has been demonstrated 


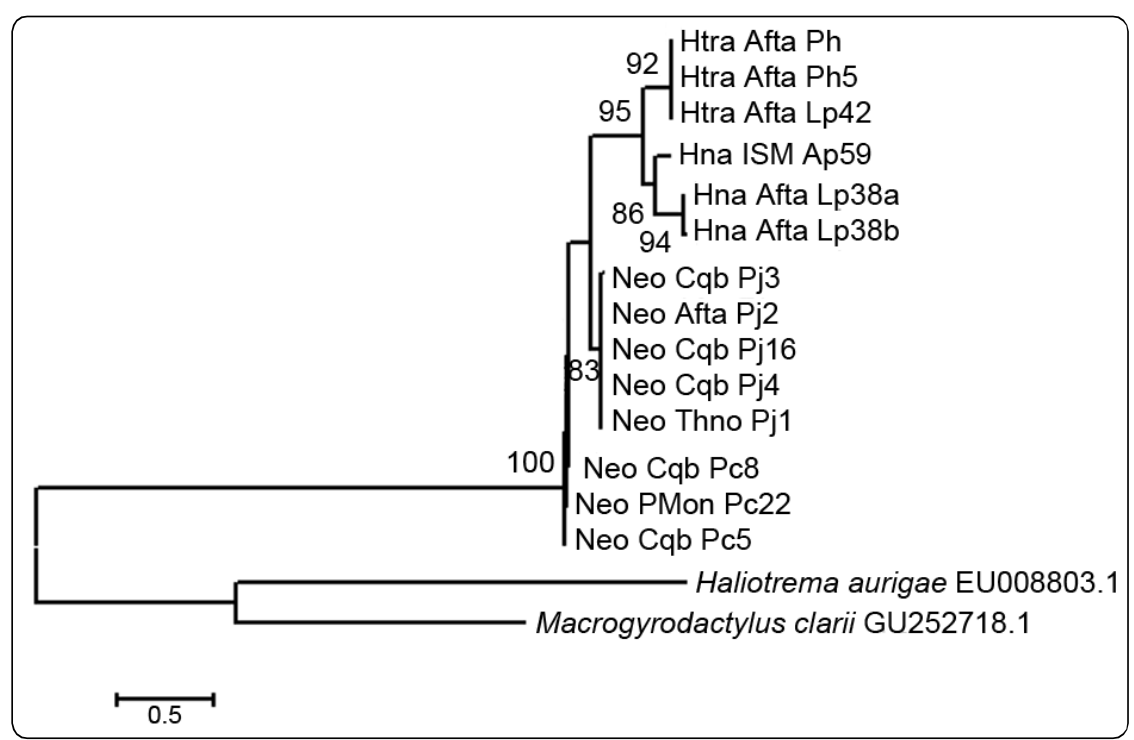

Figure 2. Phylogenetic tree of 3 digenean species present in littoral fish species from Chilean coast, based on gen CO-I using Neighbor Joining algorithm. Helicometra fasciata (Htra), Helicometrina nimia (Hna) and Neolebouria georgenascimentoi (Neo). Fish: Acanthistius pictus (Ap), Labrisomus philippii (Lp), Paralabrax humeralis (Ph), Pinguipes chilensis (Pc) and Prolatilus jugularis (Pj). Localities: Isla Santa María (ISM, $24^{\circ} \mathrm{S}$ ), Antofagasta (Afta, $24^{\circ} \mathrm{S}$ ), Coquimbo (Cqb, 30 ${ }^{\circ} \mathrm{S}$ ), Talcahuano (Thno, $36^{\circ} \mathrm{S}$ ), and Puerto Montt (PMon, $\mathbf{4 0}^{\circ} \mathrm{S}$ ) / Árbol filogenético de 3 especies digeneas presente en peces litorales de la costa chilena, basado en el gen COI usando el algoritmo Neighbor Joining. Helicometra fasciata (Htra), Helicometrina nimia (Hna) y Neolebouria georgenascimentoi (Neo). Peces: Acanthistius pictus (Ap), Labrisomus philippii (Lp), Paralabrax humeralis (Ph), Pinguipes chilensis (Pc) y Prolatilus jugularis (Pj). Localidades: Isla Santa María (ISM,24 $\left.{ }^{\circ} \mathrm{S}\right)$, Antofagasta (Afta, $\left.24^{\circ} \mathrm{S}\right)$, Coquimbo (Cqb, $\left.30^{\circ} \mathrm{S}\right)$, Talcahuano (Thno, $\left.36^{\circ} \mathrm{S}\right)$ y Puerto Montt (PMon, $40^{\circ} \mathrm{S}$ )

that parasite body size may be constrained by host longevity (Sorci et al. 1999) and host size (Morand et al. 1996). Thus, the high fecundity and body size of $H$. fasciata, H. nimia and N. georgenascimentoi, could be mainly explained by host body sizes, however, host habitat, host feeding and/or host behaviour may also have some influence (Morand \& Guégan 2000, Poulin 2007, Tschirren et al. 2007), for example, $P$. chilensis lives associated with seaweed (L. trabeculata and Macrocystis spp.), while $P$. jugularis inhabits sandy areas; these fish also have different diets (Medina et al. 2004), which may indirectly influences the parasite diets, and consequently affect the parasite fecundity (Heimpel et al. 1997).

Inside the host, a parasite is subjected to selective pressures due to food resources (= host nutrients) and host inmunocompetence, being suggested that such constraints or advantages could have some influence on the parasite life-history traits (Trouve et al. 1998), which, in turn, might determine host-specific levels of parasite abundances (Sassal et al. 1999, Krasnov et al. 2006). Oliva \& Alvarez (2011) studied the relationship between fecundity, worm size, and abundance of the adult digenean Proctoeces lintoni (Fellodistomidae) in 4 gastropod hosts (Fissurella spp.) and in the clingfish Sicyases sanguineus from northern Chile. These authors recorded that parasites of the keyhole limpet $F$. limbata and the clingfish showed the highest mean fecundity, intensity and prevalence; and therefore, they considered that $P$. lintoni shows the best fitness in those hosts. In our study, H. fasciata showed higher fecundity, and higher mean intensity and prevalence, in $P$. humeralis, which could suggest that $H$. fasciata shows the best fitness in $P$. humeralis. This positive relationship between parasite fecundity and mean abundance/prevalence could be explained by increased availability and/or accessibility of infected prey (= intermediate hosts) to fish population of $P$. humeralis. Another plausible explanation can be an increased consumption rate of intermediate prey; thereby, an increased likelihood of getting infected prey (increasing parasite abundance/ intensity), and in turn, the host could provides a suitable environment ( $=$ more nutrients) that promotes the growth of individual parasites with consequent higher fecundity. Unfortunately, it is not known how many intermediate host species are involved in the life cycle of the digeneans examined, and therefore, we cannot speculate about the role of intermediate host availability in the parasite transmissions.

In the last decades, the use of molecular markers has 
been considered a powerful tool in taxonomy, allowing to assess whether or not morphological variations correspond to different species or to phenotypic expressions of the same species due to environmental variability (Hebert et al. 2004, Radulovici et al. 2010). Our molecular analyses demonstrated that $H$. nimia from $L$. philippii and N. georgenascimentoi from $P$. jugularis and $P$. chilensis are different species; which could explain their significant differences in parasite body sizes and lower mean fecundity in these hosts (see Figs. 1 and 2, Table 2). Nevertheless, $N$. georgenascimentoi and H. nimia showed higher prevalence and mean abundance in $P$. jugularis and L. philippii, respectively, which is concordant with host specificity (Sasal et al. 1999)

The growth and fecundity of helminths can be affected by density-dependence (Shostak \& Scott 1993, Tompkins \& Hudson 1999, Dezfuli et al. 2002). For example, in an acanthocephalan/fish system, it was observed that egg production by female worms decreased significantly as the infrapopulation size increased, suggesting a densitydependent reduction in female worm fecundity (Hassanine \& Al-Jahdali 2008). In our study, generalized lineal models supported that biological traits of the digeneans were not influenced by intensity of infection. On the other hand, GLM showed that in the studied digeneans, fecundity was positively correlated with PBL, which is in concordance with reports for other helminth parasites, such as monogeneans, nematodes and acanthocephalans (Sasal et al. 1999, Richards \& Lewis 2001, Hassanine \& Al-Jahdali 2008).

In summary, body size and consequently fecundity of digeneans varied significantly among host fish species, which is apparently associated with host size species because longer parasites (with more eggs by parasite) were recorded in those longer fish species ( $P$. humeralis, A. pictus and $P$. chilensis). These results are in agreement with reports for monogeneans (Sasal et al. 1999), copepods (González et al. 2012) and nematodes (Morand et al. 1996, Koprivnikar\&Randhawa 2013). However, these results should be cautiously interpreted for the digeneans $H$. nimia (of L. philippii) and $N$. georgenascimentoi (of $P$. jugularis), which correspond to different species as it has been shown with molecular markers. Given the influence that host specificity/generality could have on parasite biological traits; further studies are necessary to advancing in our understanding of the transmission dynamics of the parasites.

\section{ACKNOWLEDGMENTS}

Authors give thanks to anonymous reviewers and the editor, Gabriela Muñoz, for their suggestions. This study was funded by Project FONDECYT No 11090149 granted to MTG. Molecular analyses were funded by Project INNOVA-CORFO 09CN145829 granted to MTG.

\section{LITERATURE CITED}

Bray RA. 2002. Three species of plagioporine opecoelids (Digenea), including a new genus and two new species, from marine fishes from off the coast of Chile. Systematic Parasitology 51: 227-236.

Bush AO, KD Lafferty, JM Lotz \& AW Shostak. 1997. Parasitology meets ecology in its own terms: Margolis revisited. The Journal of Parasitology 83: 575-583.

Cisternas F \& W Sielfeld. 2008. Habitat overlap of Paralabrax humeralis (Cuvier \& Valenciennes, 1828), Hemilutjanus macrophthalmos (Tschudi, 1845), and Acanthistius pictus (Tschudi, 1845) (Pisces; Serranidae) in the rocky subtidal south of Iquique, Chile. Latin American Journal of Aquatic Research 36: 153-158.

Dezfuli BS, S Volponi, I Beltrami \& R Poulin. 2002. Intraand interspecific density-dependent effects on growth in helminth parasites of the cormorant, Phalacrocorax carbo sinensis. Parasitology 124: 537-544.

Efron B. 1982. The jackknife, the bootstrap, and other resampling plans. CBMS-NSF Regional Conference Series in Applied Mathematics. Monograph 38: 1-92. Society for Industrial and Applied Mathematics, Philadelphia.

Gemmill AW, ME Viney \& AF Read. 2000. The evolutionary ecology of host-specificity: experimental studies with Strongyloides ratti. Parasitology 120: 429-437.

González MT \& R Poulin. 2005. Spatial and temporal predictability of the parasite community structure of a benthic marine fish along its distributional range. International Journal for Parasitology 35: 1369-1377.

González MT, C Molinet, B Arenas, G Asencio \& J Carvajal. 2012. Fecundity of sea louse Caligus rogercresseyi on native host Eleginops maclovinus captured around salmon farms from Southern Chile. Aquaculture Research 43: 853-860.

Hall KA, TH Cribb \& SC Barker. 1999. V4 region of small subunit rDNA indicates polyphyly of the Fellodistomidae (Digenea), which is supported by morphology and lifecycle data. Systematic Parasitology 4: 81-92.

Hassanine RM \& M Al-Jahdali. 2008. Intraspecific densitydependent effects on growth and fecundity of Diplosentis nudus (Harada, 1938) Pichelin et Cribb, 2001 (Acanthocephala, Cavisomidae). Acta Parasitologica 53: 289-295. 
Hebert PD, EH Penton, JM Burns, DH Janzen \& W Hallwachs. 2004. Ten species in one: DNA barcoding reveals cryptic species in the neotropical skipper butterfly Astraptes fulgerator. Proceedings of the National Academy of Sciences 101: 14812-14817.

Heimpel GEJ, A Rosenheim \& D Kattari. 1997. Adult feeding and lifetime reproductive success in the parasitoid Aphytis melinus. Entomologia Experimentalis et Applicata 83: 305315 .

Herreras MV, FE Montero, DJ Marcogliese, JA Raga \& JA Balbuena. 2007. Comparison of a manual and an automated method to estimate the number of uterine eggs in anisakid nematodes: to Coulter or not to Coulter. Is that the question? Journal of Parasitology 93: 423-425.

Jones A, RA Bray \& DI Gibson. 2005. Key to Trematode. Volume 2: 1-745. The Natural History Museum, CABI Publishing, London.

Karvonen A, GH Cheng, O Seppala \& ET Valtonen. 2006. Intestinal distribution and fecundity of two species of Diplostomum parasites in definitive hosts. Parasitology 132: 357-362.

Kimura M. 1980. A simple method for estimating evolutionary rate of base substitutions through comparative studies of nucleotide sequences. Journal of Molecular Evolution 16: 111-120.

Koprivnikar J \& HS Randhawa. 2013. Benefits of fidelity: does host specialization impact nematode parasite life history and fecundity? Parasitology 140: 587-597.

Krasnov BR, IS Khokhlova, NV Burdelova, NS Mirzoyan \& AA Degen. 2004. Fitness consequences of densitydependent host selection in ectoparasites: testing reproductive patterns predicted by isodar theory in fleas parasitizing rodents. Journal of Animal Ecology 73: 815820.

Krasnov BR, GI Shenbrot, IS Khokhlova \& R Poulin. 2006. Is abundance a species attribute? An example with haematophagous ectoparasites. Oecologia 150: 132-140.

Leung TLF, KM Donald, DB Keeney, AV Koehler, RC Peoples \& R Poulin. 2009. Trematode parasites of Otago Harbour (New Zealand) soft-sediment intertidal ecosystems: life cycles, ecological roles and DNA barcodes. New Zealand Journal of Marine and Freshwater Research 43: 857-865.

Medina M, M Araya \& C Vega. 2004. Alimentación y relaciones tróficas de peces costeros de la zona norte de chile. Investigaciones Marinas 32: 33-47.

Meeusen ENT \& A Balic. 2000. Do eosinophils have a role in the killing of helminth parasites? Parasitology Today 16: 95-101.
Morand S. 1996. Life-history traits in parasitic nematodes: a comparative approach for the search of invariants. Functional Ecology 10: 210-218.

Morand S \& G Sorci. 1998. Determinants of life-history evolution in nematodes. Parasitology Today 14: 193-196.

Morand S \& J-F Guégan. 2000. Distribution and abundance of parasite nematodes: ecological specialization, phylogenetic constraints or simply epidemiology? Oikos 88: 563-573.

Oliva ME \& C Alvarez. 2011. Is a vertebrate a better host for a parasite than an invertebrate host? Fecundity of Proctoeces cf lintoni (Digenea: Fellodistomidae), a parasite of fish and gastropods in northern Chile. Parasitology Research 109: 1731-1734.

Pietrock M \& DJ Marcogliese. 2003. Free-living endohelminth stages: at the mercy of environmental conditions. Trends in Parasitology 19: 293-299.

Poulin R. 1996. The evolution of body size in the Monogenea: the role of fish size and latitude. Canadian Journal of Zoology 74: 726-732.

Poulin R. 1999. Body size vs. abundance among parasite species: positive relationships? Ecography 22: 246-250.

Poulin R. 2006. Variation in infection parameters among populations within parasite species: intrinsic properties versus local factors. International Journal for Parasitology 36: $877-885$.

Poulin R. 2007. Evolutionary ecology of parasites, 332 pp. Princeton University Press, Princeton.

Poulin R \& D Mouillot. 2004. The relationship between specialization and local abundance: the case of helminth parasites of birds. Oecologia 140: 372-378.

Quinn GP \& MJ Keough. 2002. Experimental design and data analysis for biologists, $556 \mathrm{pp}$. Cambridge University Press, Cambridge.

Radulovici AE, P Archambault \& F Dufresne. 2010. DNA barcodes for marine biodiversity: Moving fast forward? Diversity 2: 450-472.

Richards DT \& JW Lewis. 2001. Fecundity and egg output by Toxocara canis in the red fox, Vulpes vulpes. Journal of Helminthology 75: 157-164.

Riquelme C, M George-Nascimento \& L Balboa. 2006. Morphometry and fecundity of Profilicollis bullocki Mateo, Cordova, Guzman 1982 (Acanthocephala: Polymorphidae) in sympatric coastal bird species of Chile. Revista Chilena de Historia Natural 79: 465-474.

Sasal P, S Trouvé, C Müller-Graf \& S Morand. 1999. Specificity and host predictability: a comparative analysis among monogenean parasites of fish. Journal of Animal Ecology 68: 437-444. 
Shostak AW \& ME Scott. 1993. Detection of densitydependent growth and fecundity of helminthes in natural infections. Parasitology 106: 527-539.

Tompkins DM \& PJ Hudson. 1999. Regulation of nematode fecundity in the ring-necked pheasant (Phasianus colchicus) not just density dependence. Parasitology 118: 417-423.

Trouve S, P Sasal, J Jourdane, F Renaud \& S Morand. 1998. The evolution of life-history traits in parasitic and free-living platyhelminthes: a new perspective. Oecologia 115: 370-378.
Tschirren B, LL Bischoff, V Saladin \& H Richner. 2007. Host condition and host immunity affect parasite fitness in a bird-ectoparasite system. Functional Ecology 21: 372378.

Zar J. 1999. Biostatistical analysis, 663 pp. Prentice-Hall, Upper Saddle River.

Received 5 June 2013 and accepted 27 June 2013

Associated Editor: Gabriela Muñoz 